\title{
Complete small subunit rRNA gene sequence of the scuticociliate Miamiensis avidus pathogenic to olive flounder Paralichthys olivaceus
}

\author{
Sung-Ju Jung*, Shin-Ichi Kitamura, Jun-Young Song, Il-Yong Joung, Myung-Joo Oh \\ Department of Aqualife Medicine, Yosu National University, San 96-1, Dunduck, Yosu, Chunnam 550-749, Korea
}

\begin{abstract}
Eight isolates of Miamiensis avidus (scuticociliates) were collected from olive flounder Paralichthys olivaceus with symptoms of severe ulcers and haemorrhages at several culture farms in 1999 and 2003. Cloned strains were produced and the complete small subunit ribosomal RNA gene (SSU rRNA) of each strain was sequenced for classification and phylogenic study. The SSU rRNA is $1759 \mathrm{bp}$ in length and the sequence was deposited in the GenBank under accession number AY550080. All 8 strains exhibited the same sequence, but this sequence did not match any previously deposited scuticociliate SSU rRNA sequence. Phylogenetic analysis placed Miamiensis avidus in a sister lineage to Cohnilembus verminus, Pseudocohnilembus hargisi and P. marinus.
\end{abstract}

KEY WORDS: Scuticociliatida - Miamiensis avidus - Small subunit rRNA • Olive flounder . Paralichthys olivaceus · Phylogeny

Resale or republication not permitted without written consent of the publisher

\section{INTRODUCTION}

Scuticociliates are serious pathogens in worldwide marine aquaculture, causing mass mortalities in fish and crustaceans such as the olive flounder Paralichthys olivaceus (Yoshinaga \& Nakazoe 1993, Jee et al. 2001, Kwon et al. 2003), turbot Scophthalmus maximus (Dyková \& Figueras 1994, Sterud et al. 2000, Iglesias et al. 2001), sea bass Dicentrarchus labrax (Dragesco et al. 1995), southern bluefin tuna Thunnus maccoyi (Munday et al. 1997), American lobster Homarus americanus (Cawthorn et al. 1996, Cawthorn 1997), blue crab Callinectes sapidus (Messick \& Small 1996) and seahorse Hippocampus erectus (Thompson \& Moewus 1964). In Korea, commercially significant occurrences of scuticociliatosis in the olive flounder were first noted in 1990 (Chun 2000). The ciliate infects the gills, skin, muscles and visceral organs, including the intestine, heart, and brain. It is highly histophagous and destroys infected tissues. The causative agent of scuticociliatosis in the olive flounder in Korea was identified by virtue of its morphological characteristics as Uronema marinum
(Jee et al. 2001). A very similar disease caused by a scuticociliate in the olive flounder was also reported in Japan (Yoshinaga \& Nakazoe 1993). The ciliate infested the internal tissues and caused mass mortalities in fry and juveniles. However, detailed identification has not been conducted yet.

Although various silver impregnation methods have been used to identify Scuticociliatida (Corliss 1953, Foissner 1991), there is still some confusion in the identification of certain species. Song \& Wilbert (2000) reidentified various marine scuticociliates and reported that 14 forms had either been misidentified or were junior synonyms. Small subunit rRNA (SSU rRNA, 18S rRNA) sequences have proven useful for identifying and comparing distantly related organisms (Hillis \& Dixon 1991, Hirt et al. 1995) because they are reasonably large (about 1800 nucleotides in length), highly conserved, and because available data have increased rapidly within the last few years. The information from these partial and complete SSU rRNA sequences has corroborated some taxonomic relationships based on ultrastructural and other morphological characters (Elwood et al. 1985). 
In this study, we produced 8 cloned strains of scuticociliates, identified as Miamiensis avidus, from olive flounder exhibiting severe symptoms of ulcer and haemorrhage in skeletal muscle. The SSU rRNA gene of the ciliates was sequenced for classification and identification of their respective phylogenic positions.

\section{MATERIALS AND METHODS}

Scuticociliates were collected from 8 different culture farms in the Wando, Jindo, and Yosu areas of Korea in 1999 and 2003; details are shown in Table 1. All olive flounder showed typical symptoms of ulcers and haemorrhages in skeletal muscle. Live ciliates were observed in wet preparations of gills, skeletal muscle and brain.

The brain was dissected and washed 3 times in Eagle's minimum essential medium (EMEM) containing high concentrations of antibiotics (500 IU ml-1 penicillin and $500 \mu \mathrm{g} \mathrm{ml} \mathrm{ml}^{-1}$ streptomycin). Small pieces of brain were inoculated onto chinook salmon embryo (CHSE-214) cells in $25 \mathrm{~cm}^{2}$ tissue-culture flasks. After 3 to $7 \mathrm{~d}$, each strain was cloned 5 times using the limiting dilution method in 96 well tissueculture plates of cultured CHSE-214 cells. The CHSE-214 cells were cultured in EMEM, supplemented with $10 \%$ foetal bovine serum (FBS), penicillin $\left(50 \mathrm{IU} \mathrm{ml}^{-1}\right)$ and streptomycin $\left(50 \mu \mathrm{g} \mathrm{ml}^{-1}\right)$ at $20^{\circ} \mathrm{C}$. The ciliates were sub-cultured and maintained in CHSE-214 cells, and grew to a titre of $10^{5}$ to $10^{6}$ cells $\mathrm{ml}^{-1}$ in 5 to $7 \mathrm{~d}$.

Cultured ciliates $(1 \mathrm{ml})$ were harvested by centrifugation at $2000 \times g$ for $5 \mathrm{~min}$. The cells were washed with EMEM without FBS, suspended with $170 \mu \mathrm{l}$ of TE (Tris-EDTA) buffer, to which $20 \mu$ of Proteinase K (20 $\mathrm{mg} \mathrm{ml}^{-1}$; TaKaRa) and $10 \mu \mathrm{l}$ of $10 \%$ sodium dodecyl sulfate (SDS) was added. The mixture was incubated at $55^{\circ} \mathrm{C}$ for $2 \mathrm{~h}$. Total nucleic acids were extracted

Table 1. Miamiensis avidus. Scuticociliate isolates from Korean flounder Paralichthys olivaceus included in this study

\begin{tabular}{|lccc|}
\hline Strain & $\begin{array}{c}\text { Sampling } \\
\text { site }\end{array}$ & $\begin{array}{c}\text { Sampling date } \\
(\mathrm{d} / \mathrm{mo} / \mathrm{yr})\end{array}$ & $\begin{array}{c}\text { Fish body } \\
\text { weight }(\mathrm{g})\end{array}$ \\
\hline SJF-03A & Wando & $21 / 10 / 2003$ & 208 \\
SJF-03B & Wando & $21 / 10 / 2003$ & 170 \\
SJF-03C & Wando & $9 / 11 / 2003$ & 33 \\
SJF-03D & Jindo & $28 / 11 / 2003$ & 88 \\
WS1 & Wando & $20 / 08 / 2003$ & 190 \\
YK1 & Youngkwang & $26 / 11 / 2003$ & 200 \\
YK2 & Youngkwang & $26 / 11 / 2003$ & 182 \\
YS1 & Yosu & $22 / 05 / 1999$ & 70 \\
\hline
\end{tabular}

using Trizol regent (Gibco BRL) and chloroform. Nucleic acids were precipitated with isopropanol, resuspended with distilled water, and stored at $-20^{\circ} \mathrm{C}$ until use. Universal primers A (5'-ACCTGGTTGATCCTGCCAGT-3') (primer 1) and B (5'-TGATCCTTCTGCAGGTTCACCTAC-3') (primer 6) as described by Sogin (1990) were used to amplify the SSU rRNA gene of the ciliates. PCR reactions were performed in a final reaction mixture volume of $20 \mu \mathrm{l}$ containing $50 \mathrm{mM}$ $\mathrm{KCl}, 10 \mathrm{mM}$ Tris- $\mathrm{HCl}$ (pH 9.0), $1.5 \mathrm{mM} \mathrm{MgCl}_{2}, 0.1 \%$ Triton X-100, $100 \mathrm{pM}$ of each primer, $0.2 \mathrm{mM}$ each dNTP, 1 U of Taq DNA polymerase, and template DNA. PCR amplification was performed in a GeneAmp 2400 DNA thermal cycler (Perkin Elmer) with 40 amplification cycles $\left(93.5^{\circ} \mathrm{C}\right.$ for $30 \mathrm{~s}, 50^{\circ} \mathrm{C}$ for $30 \mathrm{~s}$, and $72^{\circ} \mathrm{C}$ for $\left.2 \mathrm{~min}\right)$. The purity and size of the amplified products were analysed by electrophoresis on $1.5 \%$ agarose gels. The gels were stained with ethidium bromide and visualized under UV light.

Amplified PCR products of the expected length were cut from the gel and purified using the QIAquick Gel Extraction Kit (Qiagen). The purified PCR products were ligated into the pCR 2.1 T-vector (Invitrogen) using standard protocols. The subcloned plasmid was transformed into Escherichia coli TOP10 (Invitrogen). This plasmid was extracted from cultured E. coli TOP10 and used for sequencing. Sequencing was performed by the dideoxynucleotide chain-termination method in an automated ABI PRISM 310 DNA sequencer (PE Biosystems) using the ABI PRISM BigDye Terminator Cycle Sequencing FS Ready Reaction Kit (PE Biosystems) and the universal primer set of M13 and RV. DNA samples were sequenced in both directions and from several separate amplifications with terminal primers (primers 1 and 6) and internal primers. The internal primers used were primer 2 (5'-CTATCAGCTTTCGATGGT-3'), primer 3 (5'-GTAGGCTCTTTACCTTGA-3'), primer 4 (5'-CAAATCACTCCACCAACT-3'), and primer 5 (5'-ACGACTTCTCCTTCCTCT-3').

The sequences were aligned with other SSU rRNA gene sequences using Genetyx Win Ver. 5.1 software. Sites containing gaps were excluded from phylogenetic analysis to reduce systematic errors. Alignments were analysed with the MEGA program (Kumar et al. 1994) to produce neighbour-joining (NJ) trees using the Kimura 2-parameter model. Confidence in the NJ trees was determined by analysing 1000 bootstrap replicates using the MEGA program. The nucleotide sequences used in this paper are available from the GenBank/EMBL databases under the following accession numbers: Anophryoides haemophila U51554, Cohnilembus verminus Z22878, Cyclidium glaucoma Z22879, Cyclidium plouneouri U27816, Dexitrichides pangi AY212805, Glauconema trihymene AY169274, 
Mesanophrys carcini AY103189, Metanophrys similis AY314803, Paralembus digitiformis AY297715, Paranophrys magna AY103191, Parauronema longum AY212807, Pleuronema coronatum AY103188, Pseudocohnilembus hargisi AY212806, Pseudocohnilembus marinus Z22880, Schizocaryum dogieli AF527756, Uronema acuminata U83128, Uronema belkae AF182821, Uronema elegans AY103190, and Uronema marinum Z22881.

\section{RESULTS AND DISCUSSION}

The ciliate in this study, was morphologically identified as Miamiensis avidus Thompson \& Moewus (1964) when stained with silver nitrate and silver carbonate. It had a pointed anterior and rounded posterior end and measures 26 to $40 \times 16$ to $28 \mu \mathrm{m}$. A paroral membrane consisting of 2 parts separated by a narrow gap and 3 oral polykinetids, forms the buccal apparatus. The number of ciliary rows was 13 to 14 and the last kinety was terminated midway along membranelle 1 . The contractile vacuole was in the second end of the somatic kinety. $M$. avidus is opportunistic ectoparasite which was originally isolated from seahorses (Thomson \& Moewus 1964). The ciliate also detected from olive flounder in China, and its morphological characteristics were well described by Song \& Wilbert (2000). However, no molecular information has so far been presented on $M$. avidus. The SSU rRNA of the $M$. avidus, in this study was 1759 bp in length, including the regions corresponding to the forward (20 nucleotides [nt]) and reverse (24 nt) amplification primers. The sequences of all 8 strains obtained from olive flounder farms in 4 different regions, were $100 \%$ homologous. The sequences were deposited in GenBank under accession number AY550080. The sequences did not show $100 \%$ identity to any other deposited sequence; the sequence was $95.62 \%$ homologous to that of Anophryoides haemophila, $94.78 \%$ to that of Parauronema longum, 94.21\% to that of Schizocaryum dogieli and $94.13 \%$ to that of Cohnilembus verminus. The guanine + cytosine (GC) content was $44.61 \%$, which is in the same range as that of most other ciliates. Phylogenetic analysis showed that the ciliates are included in the phylum Ciliophora within the subclass Scuticociliatida, as a sister lineage to
Cohnilembus verminus, Pseudocohnilembus hargisi, and $P$. marinus (Fig. 1).

A similar scuticociliate infection in the olive flounder was reported with the same symptoms in Korea (Jee et al. 2001), where the arrangement and shape of the buccal structure led researchers to identify the ciliate as Uronema marinum, using the silver staining method. However, all 8 strains isolated from 8 different locations exhibited morphological characteristics of Miamiensis avidus. We conducted experimental infections of $M$. avidus with the YS1 and SJF03D strains, and confirmed severe ciliate infection in muscle, brain, and gills, with the same symptoms as seen in naturally infected fish, including ulcers around the mouth and in the skeletal muscles (data not shown). From these results, we hypothesize that $M$. avidus is a major species of scuticociliate pathogenic to olive flounder in the southern and western coastal areas of Korea. Further studies need to be conducted on the possible existence of other species of scuticociliate in culture farms and their pathogenicity to olive flounder.

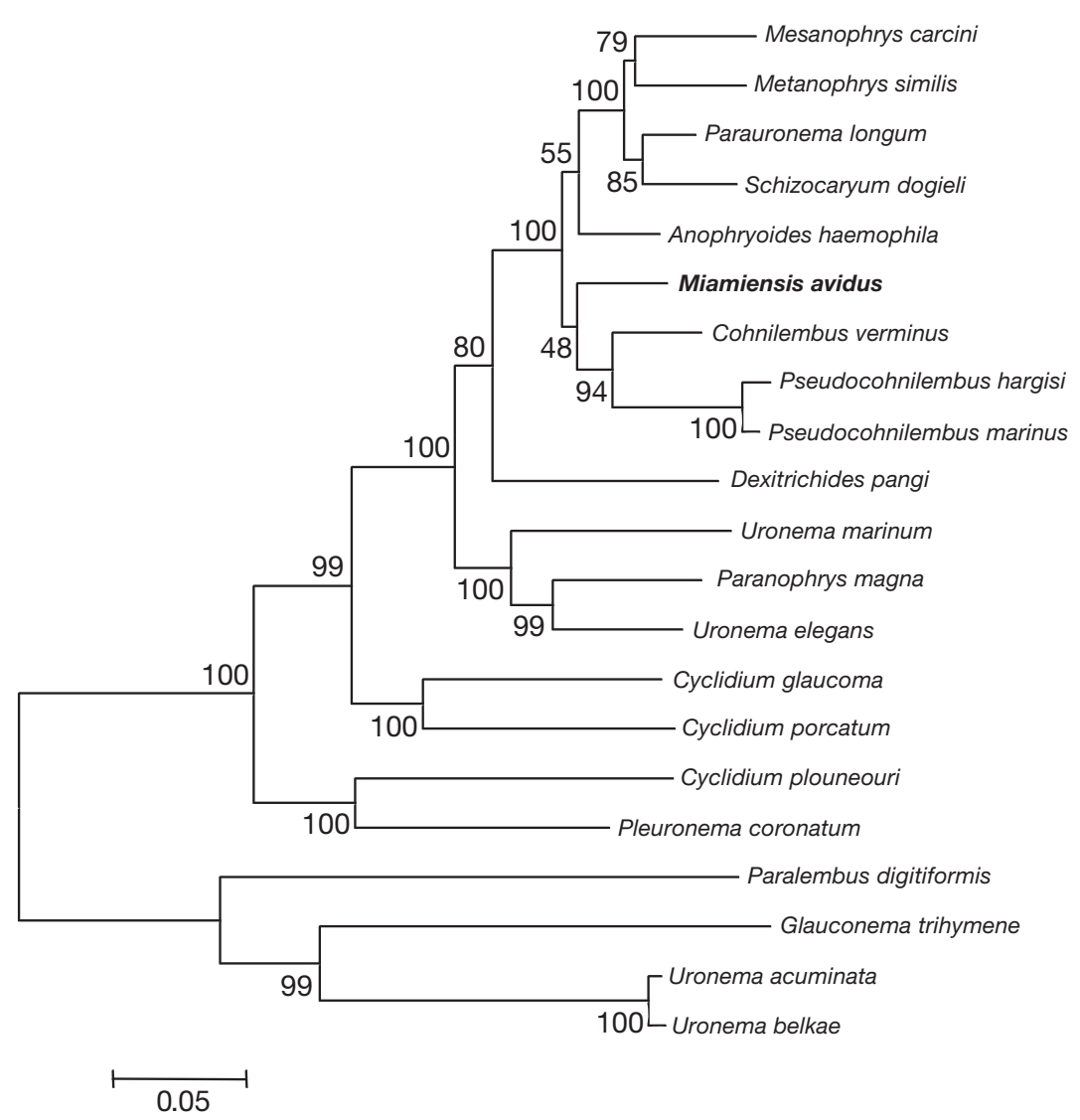

Fig. 1. A small subunit rRNA tree derived from evolutionary distances showing the phylogenic position of Miamiensis avidus. The numbers at the nodes represent the bootstrap percentages of 1000 replicates, in the neighbourjoining (NJ) method. The new sequence is shown in boldface 
Acknowledgements. This work was supported by grant No. R1-2003-000-10604-0 from the Basic Research Program of the Korean Science \& Engineering Foundation.

\section{LITERATURE CITED}

Cawthorn RJ (1997) Overview of 'Bumper car disease' impact on the North American lobster fishery. Int J Parasitol 27:167-172

Cawthorn RJ, Lynn DH, Despres B, MacMillan R, Maloney R, Loughlin M, Bayer R (1996) Description of Anophryoides haemophila n. sp. (Scuticociliatida: Orchitophryidae), a pathogen of American lobsters Homarus americanus. Dis Aquat Org 24:143-148

Chun SK (2000) Scuticociliatosis, diseases of cultured and marine fish. Hanguk Susan Sinbo Press, Seoul (in Korean)

Corliss JO (1953) Silver impregnation of ciliated protozoa by the Chatton-Lwoff technique. Stain Technol 28:97-100

Dragesco A, Dragesco J, Coste F, Gasc C, Romestand B, Raymond J, Bouix G (1995) Philasterides dicentrarchi, n. sp. (Ciliophora, Scuticociliatida), a histophagous opportunistic parasite of Dicentrachus labrax (Linnaeus, 1758), a reared marine fish. Eur J Protistol 31:327-340

Dyková I, Figueras A (1994) Histopathological changes in turbot Scophthalmus maximus due to a histophagous ciliate. Dis Aquat Org 18:5-9

Elwood HJ, Olsen GJ, Sogin ML (1985) The small subunit ribosomal RNA gene sequences from the hypotrichous ciliates Oxytricha nova and Stylonychia pustulata. Mol Biol Evol 2:399-410

Foissner W (1991) Basic light and scanning electron microscopic methods for taxonomic studies of ciliated protozoa. Eur J Protistol 27:313-330

Hillis DM, Dixon MT (1991) Ribosomal DNA: molecular evolution and phylogenetic inference. Q Rev Biol 66:411-446

Hirt RP, Dyal PL, Wilkinson M, Finlay BJ, Roberts DM, Embley TM (1995) Phylogenetic relationships among Karyorelictids and Heterotrichs inferred from small subunit rRNA sequences: Resolution at the base of the ciliate tree. Mol Phylogenet Evol 4:77-87

Iglesias R, Paramá A, Alvarez MF, Leiro J, Fernández J, San-

Editorial responsibility: Wolfgang Körting,

Hannover, Germany martin ML (2001) Philasterides dicentrarchi (Ciliophora, Scuticociliatida) as the causative agent of scuticociliatosis in farmed turbot Scophthalmus maximus in Galicia (NW Spain). Dis Aquat Org 46:47-55

Jee BY, Kim YC, Park MS (2001) Morphology and biology of parasite responsible for scuticociliatosis of cultured olive flounder Paralichthys olivaceus. Dis Aquat Org 47:49-55

Kumar S, Tamura K, Nei M (1994) MEGA: molecular evolutionary genetics analysis software for microcomputers. Comput Appl Biosci 10:189-191

Kwon SR, Kim CS, Kim KH (2003) Differences between shortand long-term cultures of Uronema marinum (Cliophora: Scuticociliatida) in chemiluminescence inhibitory activity, antioxidative enzyme and protease activity. Aquaculture 221:107-114

Messick GA, Small EB (1996) Mesanophrys chesapeakensis $\mathrm{n}$. sp., a histophagous ciliate in the blue crab, Callinectes sapidus, and associated histopathology. Invertebr Biol 115: $1-12$

Munday BL, O'Donoghue PJ, Watts M, Rough K, Hawkesford $T$ (1997) Fatal encephalitis due to the scuticociliata Uronema nigricans in sea-caged, southern bluefin tuna Thunnus maccoyii. Dis Aquat Org 30:17-25

Sogin ML (1990) Amplification of Ribosomal RNA Genes for Molecular Evolution Studies. In: Innis MA, Gelfand DH, Sninsky JJ, White TJ (eds) PCR protocols: a guide to methods and applications. Academic Press, San Diego, CA

Song W, Wilbert N (2000) Redefinition and redescription of some marine Scuticociliates from China, with report of a new species, Metanophrys sinensis nov. sp. (Ciliophora, Scuticociliatida). Zool Anz 239:45-74

Sterud E, Hansen MK, Mo TA (2000) Systemic infection with Uronema-like ciliates in farmed turbot Scophthalmus maximus (L.). J Fish Dis 23:33-37

Thompson JC, Moewus L (1964) Miamiensis avidus n. g., n. $\mathrm{sp}$, a marine facultative parasite in the ciliate order Hymenostomatida. J Protozool 11:378-381

Yoshinaga T, Nakazoe J (1993) Isolation and in vitro cultivation of an unidentified ciliate causing scuticociliatosis in Japanese flounder (Paralichthys olivaceus). Gyobyo Kenkyu 28:131-134

Submitted: April 29, 2004; Accepted: September 22, 2004

Proofs received from author(s): March 23, 2005 